О. В. Лінчевський, В. М. Черненко, Ю. С. П’ятницький, І. Є. Булах Міністерство охорони здоров'я України

\title{
ШЛЯХИ РЕФОРМУВАННЯ СИСТЕМИ ВИЩОЇ МЕДИЧНОЇ ОСВІТИ В УКРАЇНI В СУЧАСНИХ УМОВАХ
}

\author{
O. V. Linchevskyi, V. M. Chernenko, Yu. S. Piatnytskyi, I. Ye. Bulakh \\ The Ministry of Healhcare of Ukraine

\section{THE WAYS OF HIGHER MEDICAL EDUCATION SYSTEM REFORMING IN UKRAINE IN THE MODERN CONTEXT}

\begin{abstract}
Пошук стандартів вищої медичної освіти є оптимальною стратегією досягнення концептуально нового рівня якості підготовки майбутніх фахівців, основою якого є підготовка медичних працівників відповідно до загальноприйнятих міжнародних норм викладання з урахуванням особливостей та інтересів національної системи охорони здоров'я. Серед першочергових завдань діяльності вищих навчальних закладів та закладів післядипломної освіти у новому навчальному році будуть приведення змісту комп’ютерних програм для атестації інтернів та слухачів у відповідність до положень сучасних протоколів лікування та стандартів діагностики; приведення навчально-методичного забезпечення навчального процесу у відповідність до змісту сучасних стандартів вищої освіти, сучасних протоколів лікування та стандартів діагностики тощо.
\end{abstract}

Ключові слова: реформи; вища медична освіта.

Searching of standards in higher medical education is the best strategy to achieve conceptually new level of quality of training future professionals, which bases on the training of health workers in accordance with generally accepted international standards of teaching and allowing for the interests of the national health system. Among the priority tasks of universities and graduate schools in the new school year will be putting the content software certification for interns and students in line with the current standard treatment protocols and diagnostics; putting the teaching of educational process in accordance with the content of modern higher education, current treatment protocols and standards of diagnostics.

Key words: reforms; higher medical education.

Вступ. Підписання документа про асоціацію України з Європейським Союзом означає запровадження ряду важливих змін, які розпочинаються в Україні, в тому числі в системі охорони здоров'я. В Європейському регіоні Україна має один із найгірших показників серед систем охорони здоров’ я та посідає друге місце за рівнем смертності [1]. Пошук стандартів вищої медичної освіти є оптимальною стратегією досягнення концептуально нового рівня якості підготовки майбутніх фахівців, основою якого є підготовка медичних працівників відповідно до загальноприйнятих міжнародних норм викладання з урахуванням особливостей та інтересів національної системи охорони здоров’я [2, 3].

Мета роботи - висвітлити основні шляхи розвитку сучасної вищої медичної освіти при її реформуванні.

Основна частина. У підпорядкуванні МОЗ України, як державного замовника, перебувають 17 державних вищих навчальних закладів, у яких здобува- ють освіту понад 65,7 тис. студентів, 3 них: 24,3 тис.за державним замовленням, 41,4 тис. - за кошти фізичних та юридичних осіб. У вищих медичних (фармацевтичному) навчальних закладах навчаються на умовах контракту 23,3 тис. іноземних громадян зі 134 країн світу. Цими закладами щороку в середньому випускається близько 10 тис. спеціалістів.

Крім того, підготовка фахівців для галузі охорони здоров’ я здійснюється за трьома спеціальностями на медичних факультетах чотирьох національних університетів: Сумського, Харківського, Ужгородського та Чорноморського, які підпорядковані Міністерству освіти і науки України. Обсяги державного замовлення у 2016 році становили: по спеціальності 221 Стоматологія - 21 місце; по спеціальності 222 Медицина - 305; по спеціальності 226 Фармація - 25 місць.

У 100 медичних (фармацевтичних) навчальних закладах комунальної форми власності здійснюється підготовка молодших спеціалістів з медичною

() О. В. Лінчевський, В. М. Черненко, Ю. С. П’ятницький, І. Є. Булах 
та фармацевтичною освітою, бакалаврів з медсестринства, фармації, лабораторної діагностики та магістрів з медсестринства (з них: 23 медичних училища, 72 медичних (фармацевтичних) коледжі, 2 філії, 3 інститути медсестринства). У них навчається понад 70,4 тис. студентів. Щорічно заклади випускають до 20 тис. спеціалістів.

Підготовка медичних кадрів також здійснюється у 12 навчальних закладах недержавної форми власності.

Однією з функцій Міністерства охорони здоров’ я України є визначення вимог та забезпечення контролю якості професійної підготовки медичних та фармацевтичних кадрів. На сьогодні назріла критична необхідність модернізації системи вищої медичної та фармацевтичної освіти, приведення ії якості у відповідність до міжнародних стандартів. Досягнення цієї мети є запорукою успішної реалізації медичної реформи в Україні, яка наразі здійснюється.

Експертними міжвідомчими робочими групами, які працюють над стратегічним завданням приведення якості національної вищої медичної та фармацевтичної освіти до кращих міжнародних стандартів, визначені основні напрями для досягнення цієї мети у короткостроковій та довгостроковій перспективах:

1. Проведення порівняльного оцінювання відповідності змісту вітчизняної вищої медичної освіти міжнародним стандартам, зокрема американським, - оцінка іï стану.

2. Зменшення контингенту суб’єктів навчання, які навчаються за державним замовленням або за кошти фізичних та юридичних осіб; збільшення загальних обсягів фінансування вищих навчальних закладів.

3. Забезпечення якісного конкурсного відбору кращих абітурієнтів при вступі до вищих медичних навчальних закладів.

4. Створення мотивації для навчання студентів, сприяння їх працевлаштуванню.

5. Запровадження єдиних вимог до рівня професійних компетентностей викладачів, визначення шляхів їх мотивації до роботи.

6. Запровадження єдиних вимог для об’єктивної оцінки рівня теоретичної та практичної підготовки студентів, інтернів, слухачів під час їх атестації для визначення набутих компетентностей.

7. Запровадження нових стандартів вищої освіти, приведення навчально-методичного забезпечення навчального процесу у відповідність до змісту сучасних стандартів вищої освіти, сучасних протоколів лікування та стандартів діагностики.
Одна з перших реалізованих ініціатив Міністерства охорони здоров’ я України у напрямі реформування системи вищої медичної освіти - проведення порівняльного оцінювання відповідності змісту вітчизняної вищої медичної освіти міжнародним стандартам, зокрема американським, - оцінка їі стану. Це дослідження, у якому візьмуть участь усі студенти останнього курсу навчання та інтерни, буде проведено в усіх вищих навчальних закладах та закладах післядипломної освіти, підпорядкованих МОЗ України, упродовж березня - травня 2017 року.

3 метою оцінки відповідності змісту української медичної додипломної і післядипломної освіти міжнародним стандартам підготовки лікарів при оцінюванні студентів та інтернів під час проведення традиційних ліцензійних інтегрованих іспитів “КРОК” будуть додатково використані тестові питання USMLE (United States Medical Licensing Examination - "Екзамен з отримання медичної ліцензії Сполучених Штатів Америки”) та IFOM (International Foundations of Medicine - “Міжнародні основи медицини”), розроблені Національною радою медичних екзаменаторів Сполучених Штатів Америки (NBME - National Board of Medical Examiners).

Результати цього іспиту, які будуть проаналізовані до 01.06.2017 року, будуть об’єктивним показником ефективності існуючої системи вищої медичної освіти в Україні, якості навчальних програм, затверджених МО3 України, та використовуватимуться як критерій для прийняття МОЗ України необхідних управлінських рішень для подальшої реалізації реформ у сфері вищої медичної освіти. За результатами цього дослідження МО3 України ініціюватиме внесення відповідних змін до навчальних програм підготовки студентів та інтернів вже з 2017/2018 навчального року.

Другим напрямом реформування системи вищої медичної та фармацевтичної освіти в Україні є наближення орієнтовної середньої вартості підготовки одного фахівця до європейського рівня шляхом іï̈ поступового збільшення.

Також зазначаємо, що, відповідно до пункту 10 частини першої статті 26 Закону України “Про внесення змін до Закону України “Про вищу освіту” щодо працевлаштування випускників”, вивчення попиту на окремі спеціальності на ринку праці та сприяння працевлаштуванню випускників є одним із основних завдань вищого навчального закладу.

Відповідно до частини четвертої статті 64 цього закону, випускникам вищих медичних і педагогічних навчальних закладів, які уклали угоду про 
відпрацювання не менше трьох років у сільській місцевості або селищах міського типу, держава, відповідно до законодавства, забезпечує безоплатне користування житлом з опаленням і освітленням у межах встановлених норм.

Зазначене свідчить про необхідність актуалізації завдань роботи відділів сприяння працевлаштуванню випускників, які функціонують у вищих навчальних закладах.

Питання поліпшення якості підготовки лікарів системно обговорювалося учасниками парламентських слухань на тему “Медична освіта в Україні: погляд у майбутнє”, що відбулися у Верховній Раді України 22 березня 2017 року відповідно до Постанови Верховної Ради України від 08 лютого 2017 року № 1842-VIII, адже ряд завдань, які визначає MO3 України у своїй роботі щодо приведення якості національної вищої медичної та фармацевтичної освіти до кращих міжнародних стандартів, неможливо вирішити без участі Міністерства освіти і науки України, Міністерства фінансів України тощо. Серед конкретних пропозицій МОЗ України у цьому аспекті були ті, реалізація яких здійснюватиметься профільними міністерствами за участю Комітету Верховної Ради України з питань охорони здоров’я:

1. Комітету Верховної Ради України з питань охорони здоров’я створити робочу групу для підготовки проекту Закону України, спрямованого на створення університетських лікарень, врегулювання здійснення навчальної, науково-дослідницької, організаційно-методичної, діагностичної та лікувальної діяльності кафедр медичних університетів та наукових установ на базі державних і комунальних закладів охорони здоров'я на підставі відповідних договорів про клінічні бази.

2. Міністерству освіти і науки України затвердити в установленому порядку стандарти вищої медичної та фармацевтичної освіти з відповідних спеціальностей галузі знань “Охорона здоров’я”, затверджених Постановою Кабінету Міністрів України “Про затвердження переліку галузей знань і спеціальностей, за якими здійснюється підготовка здобувачів вищої освіти” від 29 квітня 2015 року № 266 (зі змінами, внесеними відповідно до Постанови Кабінету Міністрів України від 01.02.2017 року № 53);

переглянути та, у разі необхідності, підвищити мінімальний поріг прохідного бала для зарахування на медичні (фармацевтичні) спеціальності до вищих навчальних закладів;

вдосконалити критерії якості оцінки освітньої діяльності викладачів вищих медичних навчальних закладів та забезпечити контроль за дотриманням ними принципів академічної доброчесності;

внести зміни до кваліфікаційних характеристик у частині володіння рівнем англійської мови викладачами вищих медичних навчальних закладів не нижче рівня В2 або його еквівалента та визначити мінімально-необхідний рівень цитування їх наукових праць у міжнародних наукометричних базах;

розрахувати із залученням Міністерства фінансів України, інших зацікавлених органів центральної виконавчої влади та затвердити норматив орієнтовної середньої вартості навчання одного студента медичної (фармацевтичної) спеціальності, а також сприяти збільшенню обсягів фінансування вищих навчальних закладів, які здійснюють підготовку фахівців у галузі знань “Охорона здоров’я”;

брати до уваги позицію МОЗ України при ліцензуванні підготовки спеціалістів галузі знань “Охорона здоров’ я” у непрофільних вищих навчальних закладах МОН України та приватної форми власності, визначивши обов'язкові необхідні умови щодо матеріально-технічної бази та кадрового забезпечення;

вжити заходів для підвищення престижу роботи викладачів вищої медичної школи, рівня їх соціального захисту та заробітної плати, створення можливостей для їх самовдосконалення, стажування за кордоном, реалізації наукових ідей.

3. Міністерству економічного розвитку і торгівлі України, Міністерству фінансів України за поданням Міністерства охорони здоров’я України:

забезпечити у 2017 році та у подальші роки формування фіксованих для вищих навчальних закладів обсягів державного замовлення на підготовку та підвищення кваліфікації спеціалістів, наукових та науково-педагогічних кадрів з урахуванням:

кадрових потреб галузі охорони здоров’я, зокрема середньострокового прогнозу;

необхідності збільшення обсягів видатків державного бюджету MO3 України на підготовку фахівців з урахуванням затверджених Кабінетом Міністрів України нормативів співвідношення викладач/студент; викладач/інтерн; викладач/слухач у сфері охорони здоров'я та орієнтовної середньої вартості підготовки одного студента з урахуванням фінансових потреб вищих навчальних закладів.

Експертними міжвідомчими робочими групами також визначена необхідність затвердження МO3 України нових положень про інтернатуру, клінічну ординатуру, лікарську резидентуру, відповідних переліків спеціальностей та спеціалізацій; 
запровадження у 2017 році підготовки фахівців за спеціальностями “Педіатрія”, “Громадське здоров’я”, “Медична психологія”, “Фізична терапія, ерготерапія” відповідно до Переліку галузей знань і спеціальностей, за якими здійснюється підготовка здобувачів вищої освіти, затвердженого Постановою Кабінету Міністрів України від 01.02.2017 року № 53 “Про внесення змін до Постанови Кабінету Міністрів від 29 квітня 2015 року № 266”;

застосування об’ єктивних структурованих клінічних іспитів на додипломному етапі підготовки лікарів, як складової атестації випускників, а також на післядипломному етапі підготовки - для випускників інтернатури.

Серед першочергових завдань діяльності вищих навчальних закладів та закладів післядипломної

\section{Список літератури}

1. Проблеми та перспективи вищої медичної освіти у реалізації Національної стратегії реформування системи охорони здоров’я України / В. М. Мороз, Ю. Й. Гумінський, Л. В. Фоміна, Т. Л. Полеся // Проблеми та перспективи вищої медичної школи у розробці та реалізації Національної стратегії побудови нової системи охорони здоров’я в Україні на період 2015-2025 рр. : тези доповідей навч.-метод. конф. (Вінниця, 25 берез. 2015 р.). Вінниця, 2015. - С. 3-6.

2. Наказ МОЗ України та АМН України від 12.09.2008 р. № 522/51 “Про затвердження Концепції розвитку вищої

\section{References}

1. Moroz V.M., Huminskyi Yu.Y., Fomina, L.V., \& Polesia, T.L. (2015). Problemy ta perspektyvy vyshchoyi medychnoyi osvity u realizatsii Natsionalnoi stratehii reformuvannia systemy okhorony zdorovia Ukrainy [Problems and prospects of higher medical education in the implementation of the National Strategy for Health Reform in Ukraine]. Problemy ta perspektyvy vyshchoyi medychnoyi shkoly u rozrobtsi ta realizatsii Natsionalnoi stratehii pobudovy novoi systemy okhorony zdorovia v Ukraini na period 2015 - 2025 rr. Tezy dopovidei navchalno-metodychnoi konferentsii-Problems and prospects of higher medical education in developing and implementing the National Strategy for building a new health care system in Ukraine for the period 2015 - 2025. Abstracts of educational conference. Vinnytsia, March 25, 2015 [in Ukrainian].

2. Nakaz MOZ ta AMN Ukrainy vid 12.09.2008 № 522/51 Pro zatverdzhennia Kontseptsii rozvytku vyshchoi medychnoi osvity v Ukraini [Order of the Ministry of Healthcare освіти у новому навчальному році будуть приведення змісту комп’ютерних програм для атестації інтернів та слухачів у відповідність до положень сучасних протоколів лікування та стандартів діагностики; приведення навчально-методичного забезпечення навчального процесу у відповідність до змісту сучасних стандартів вищої освіти, сучасних протоколів лікування та стандартів діагностики тощо.

Висновок. Отже, від кількісних показників роботи медичних університетів ми маємо зробити акценти на питаннях якості підготовки лікарів та провізорів у контексті вже запроваджених змін законодавства щодо реформування сфери охорони здоров’я, кадрової політики, змін у системі управління і фінансування вищої освіти.

медичної освіти в Україні”. - Режим доступу : http:// mozdocs.kiev.ua/view.php?id=12141.

3. Морозова О. М. Пошук стандартів вищої медичної освіти для вдосконалення системи охорони здоров'я / О. М. Морозова, Л. В. Батюк, В. Г. Кнігавко // Актуальні питання якості медичної освіти : матеріали XIII Всеукр. наук.-практ. конф. з міжнар. участю (з дистанційним під'єднанням ВМ(Ф)НЗ України за допомогою відеоконференц-зв’язку) (Тернопіль, 12-13 трав. 2016 р.). - Тернопіль, 2016. - Т. 1. - С. 109-110.

of Ukraine № 522/51 of September 12, 2008. On approval of the Concept of development of higher medical education in Ukraine]. Retrieved from http://mozdocs.kiev.ua/view. php?id=12141 [in Ukrainian].

3. Morozova, O.M., Batiuk, L.V., \& Knihavko, V.H. (2016). Poshuk standartiv vyshchoi medychnoi osvity dlia vdoskonalennia systemy okhorony zdorovia [Searching of standards in higher medical education to improve the health care system]. Aktualni pytannia yakosti medychnoi osvity : materialy XIII Vseukrainskoi naukovo-praktychnoi konferentsii z mizhnarodnoiu uchastiu (z dystantsiinym pidyednanniam VM(F)NZ Ukrainy za dopomohoiu videokonferents-zviazku), Ternopil, 12-13 travnia 2016-Current issues of quality of medical education: materials of XIII All-Ukrainian scientific conference with international participation (with remote connectivity HM(Ph)EI of Ukraine via video-link), Ternopil May 12-13, 2016 [in Ukrainian].

Отримано 05.04.17 